\title{
A JOURNEY OF THE PEOPLE \\ OF BETHANY MARKED BY \\ DISPOSSESSION, STRUGGLE FOR \\ RETURN OF LAND AND CONTINUED \\ IMPOVERISHMENT: A CASE STUDY OF \\ LAND REFORM THAT HAS NOT YET \\ REDUCED POVERTY
}

\section{Olehile Buffel}

Department of Philosophy, Practical Theology and Systematic Theology

University of South Africa

Buffeoa@unisa.ac.za

\section{ABSTRACT}

This article investigates the history of the farm Bethany in the Free State (a province of South Africa), which was the first mission station of the Berlin Mission Society. It traces its history from the time when Adam Kok II allocated the farm to the Mission Society for the purpose of spreading the gospel to the indigenous people, and to its dispossession through the forced removals of 1939 and later in the 1960s. It argues that the history of the community is a journey from a community that was economically sustainable before the forced removal, to a journey of impoverishment caused by dispossession. After successful restitution of the farm in 1998, the community continues to be impoverished. The article argues for a restitution process that reduces and eliminates poverty and it challenges the Department of Land Affairs to partner with communities that have returned to their ancestral lands. In this partnership the weak and inadequate post-settlement support must be reviewed and improved in view of ensuring that livelihoods are enhanced and poverty reduced, if not eliminated. The article also challenges the Evangelical Lutheran Church, which still owns part of the farm through its Property Management Committee, to equally partner with the

\section{UNISA}


community members of whom the majority are members of the Lutheran Church.

Keywords: Bethany; Free State; Berlin Mission society; land dispossession; restitution; ancestral land; Evangelical Lutheran Church

\section{INTRODUCTION}

This article was prompted by a casual visit in 2013 to Bethany, a former mission station that was originally inhabited by the descendants of the Griquas, Korannas and Batswana, who were later forcefully removed from their land and scattered throughout the Free State, particularly around Edenburg, Bloemfontein, ThabaNchu and Kimberley in the Northern Cape. According to Schoeman $(1996,107)$ the inhabitants of the area, especially the Khoi descendants, had a reputation of being a very formidable tribe. These are the people whom the Dutch settlers found when they arrived at the Cape in April 1652 (Schoeman 2009, 11). The Dutch settlers called indigenous people all kinds of names that were not complimentary. Some names were derogatory, such as 'natives', 'inhabitants', 'indegenes', 'wild people' (wilden), and the most derogatory such as 'kaffirs' (Schoeman 2009, 11). They were later referred to as 'Hottentots' (Schoeman 2009, 11). They were also referred to as 'poor savages' (Thunberg cited in Crais and Scully 2009, 18). Others such as Batlhaping, a Batswana tribe in the Trans-Orange, were called the 'goat people' (Briqua) (Schoeman 2009, 90).

The author was shocked upon discovering that socio-economic conditions of residents of Bethany have not yet improved since the return of the land to the claimants of Bethany in 1999, following success of their claim in 1998. The people who have returned to their ancestral land continue to live in poverty, in an area that is still lacking in infrastructural development and basic services. The observation prompted the author to attempt a critical investigation of the journey of the descendants of the Griquas, Korannas and Batswana who successfully struggled for the return of their land. The article traces the journey of the communities of Bethany from the time of the establishment of a mission station. It looks at their life and history before their forced removal and after their return to their ancestral land. The conclusion is that those who were dispossessed of their land are still impoverished. This article challenges both the Lutheran Church and the ANC-led government to look for ways of contributing to the building of a self-reliant and sustainable community.

\section{Bethany, the first mission station of the Lutheran Church by the Berlin Mission Society}

On 17 April 1834 five missionaries under the leadership of Rev. A. Gebel arrived in Cape Town (Pakendorf 1913; Schoeman 1985, 11). The four missionaries who accompanied Rev. Gebel were Revs. F. Lange, G.A. Kraut, R.T. Gregrowsky and J. 
Smith. That was about 10 years after the establishment of the Berlin Mission Society, which was established in 1824 through the efforts of Johann Janicke (Schoeman 1997, 268). They later joined an expedition to the north and on 26 August 1834 they arrived at Philippolis, in the territory that was regarded by the Griquas as theirs, which later came to be known as the Orange Free State (Du Plessis 1911, 14; Schoeman 1985, 11). Philippolis was a mission station of the London Mission Society and also a capital of the Griqua area of Adam Kok II, which covers the area between the Orange and Modder Rivers (Schoeman 1985, 12). According to Du Plessis (1911, $14)$ and Murray $(1996,217)$ the Griqua chief, Adam Kok claimed authority over the Transorangia (Transgarieb). This referred to the Orange-Vaal triangle covering the modern Free State and Lesotho (Schoeman 2003, 11). According to Raper (1987, 319 ) in the Dictionary of Southern African place names, Transgarieb is a former name of the area north of the Orange River, specifically between the Orange and Vaal Rivers. In September 1834 the missionaries of the Berlin Mission Society arrived at a farm called Vaalbank to establish the first mission station of the Lutheran Church, after being granted permission by King Adam Kok, a king (chief/captain) of the Griquas (Berlin Mission Society 2013, 1). According to Schoeman (2002, 10) captain ('kaptein') was a title used by the Dutch as early as 1886 to indicate a leader (headman) of any large group of the Khoikhoi (Van der Stoep 2008, 77). In the process the African titles were corrupted, as even leaders of African tribes who were the equivalent of kings, were erroneously referred to as 'kapteine' or 'chiefs'.

The missionaries of the Berlin Mission Society were given a grant of land some 12 miles on a farm called Vaalbank, which was 'a historical Griqua settlement near Edenburg in the Free State' (Du Plessis 1911, 14; Venter, Marais, Van Zyl, Van Rooyen and Cloete 2010, 7). According to Murray $(1996,217)$, the original farm was about 18010 ha and was registered in 1881 on the basis of a certificate issued in 1850. The land has since been sub-divided and portions thereof sold to white farmers and finally reduced to about two-thirds of its original size (c. 11918 ha) (Murray 1996, 217).

The farm Vaalbank lay along the banks of the Riet River and around a fountain of perennial water (Du Plessis 1911, 212). According to Rev. Gebel the missionaries arrived at this fountain on 24 September 1834. Upon arrival there they said: 'Hier wil ons hutte bou! Mag God gee dat dit die hutte van vrede en seëning wees!' [Here we would like to build huts! May God make these huts of peace and blessing!] (Gebel cited in Schoeman 1985, 15). The fountain is still a source of water for Mr Johannes Kraalshoek (born 1933) and his family. Mr Kraalshoek is the leader ('Kaptein') of the Griqua community in the Free State, as well as for the community around the building of the Lutheran Church (Evangelical Lutheran Church in Southern Africa - ELCSA). The missionaries did not bother to ask the indigenous people what the indigenous name of the place was, but gave it the name 'Bethanie' (Bethanien in German). Gebel (in Schoeman 1985, 16) wrote in his report to Germany that they had desired and hoped that the place would become a place of refuge and comfort 
for the poor Korannas, just like Bethany in the New Testament (John 11:18). The indigenous name was Tsamai, according to Molema $(2012,18)$, author of the earliest book-length biography of Solomon Tshekisho Plaatje. This is the place where Sol Plaatje's grandparents settled and where he was baptised in January 1877 (Molema 2012, 18).

There missionaries found the indigenous community consisting of the Koranas, who were later joined by the Batswana (often erroneously referred to as Bechuana by the Europeans). Adam Kok, whose head-office was at Philippolis, granted permission to the Berlin Mission Society to carry out mission work, which included teaching the gospel and developing the communities in the area that is on the bank of the Riet River (Van Aswegen 1990, 230). The land was allocated to the missionaries of the Berlin Mission Society in view of enabling them to carry out church and school activities (Molema 2012,18). One of the earliest missionaries to arrive there was Rev. C.F. Wuras, whose name was given to the train station Wurasoord. According to Schoeman: 'In 1834 again $^{1}$ the Berlin Missionary Society founded the station of Bethanie near the Riet River, in Griqua territory of the Right Hand Korana of Goliat Yzerbek' (Schoeman 2005, 76; 2003, 68; 2002, 100). Murray $(1996,217)$ refers to leader Goliat Ysterbek as a sub-captain of Adam Kok. The Koranas formally submitted to the authority of the Griquas, even though they obtained a degree of selfgovernment and made local regulations (Schoeman 2002, 100). Bethany was not only inhabited by the Koranas, but also by Batswana, who were initially concentrated at Philippolis and later scattered throughout the Griqua territory. Some of them settled at Bethany (Schoeman 2002, 101).

\section{The early inhabitants of Bethany at the time of the arrival of the Berlin Mission Society, the Koranas and Batswana}

\section{Koranas}

The Koranas are the earliest inhabitants of the Transgarieb, who are regarded by some historians as part of the Khoi-Khoi community who settled north of the Gariep River (Van Aswegen 1990, 230; Visagie 2012, 97). According to Penn $(2005,163)$, the Koranas were the product of both the original Khoikhoi of the area and later migrations of Khoikhoi from the south. In fact, these descendants of the Khoikhoi were not only the first inhabitants of the Transorangia, but of South Africa. They are the people to whom we owe our being, in the words of former Deputy President and later President of the Republic of South Africa, Mr Thabo Mbeki:

1 The Bethany mission station was started after the London Mission Society had started a mission station for the refugee Chief of Batlhaping, Chief Lephoi who had hitherto been living in Philippolis under the protection of the Griquas (Schoeman 2005, 76). 
...to the Khoi and the San whose desolate souls haunt the great expanses of the beautiful Cape - they who fell victim to the most merciless genocide our nation has ever seen, they who were the first to lose their lives in the struggle to defend our freedom and dependence and they who, as a people, perished as a result. (Mbeki 1999, 153)

One of the first missionaries to arrive at Bethany refers to them as Hottentots, referring to them as 'byna suiwer Hottentotstam' [Almost pure Hottentot ancestry] (Gebel in Schoeman 1985, 12). Schoeman $(2003,13)$ refers to the Koranas as the 'pastoral Khoi people established along the Orange River in scattered small groups'. Others refer to the Koranas as nomadic cattle owners (Schoeman1985, 25; Van Aswegen 1990, 230).

They were prone to moving from one area to the other in search of water and grazing and some of them settled at Vaalbank (Bethany), near Edenburg. They were also referred to as the "herders and raiders living in a number of small, scattered tribes in the vicinity of the Riet and Modder Rivers' where they were strengthened by other groups of blacks and indigenous people (Schoeman 2003, 68). They had also formed alliances with the Griquas under Andries Waterboer and Adam Kok (Visagie 2012, 101). The Griqua leaders (kapteins) wanted the Koranas to be their subjects, however, with very limited success (Visagie 2012, 101).

\section{Batswana}

This is a group that also inhabited the Orange Free State, who also came to settle in the area that later became the Bethany Mission Station, in addition to the other mission stations of Philippolis and Bethulie (Murray 1996, 217; Schoeman 2003, 101). The missionaries did not seem to have been impressed by the way of life of the Bushmen and Koranas, but were impressed and delighted by the industry of the Batswana (Schoeman 2003, 101). One missionary, Schreiner, wrote patronisingly as follows from Philippolis: 'The Bechuanas are a peculiar source of joy and encouragement to us, the Lord is indeed showering upon this poor people the rich blessings of his grace' (Schoeman 2003, 101). Another missionary of the Berlin Mission Society, Rev. C.F. Wuras, wrote as follows: 'Since the Bechuanas have been living here, the gardens have been enlarged, so that it is true joy to me to see them when I return to Bethanie' (Wuras in Schoeman 2003, 101). Welsh cites Robert Moffat who described Batswana as 'a people of industrious habits, attentive to whatever may increase their property and comfort' (Moffat in Welsh 2000, 284). The compliments to the Bechuanas were many. Inspector Schultheiss (in Schoeman 2003) wrote as follows: 'Now the lovely waters of Bethany no longer run away unused, as the Bechuana settlers have laid out large gardens. The outside fountains too are being used for agriculture more and more, so that there will soon be more arable ground' (Schoeman 2003, 101). From these reports it appears that the residents of Bethany were good at farming and their forced removal in the 1960s brought to an end some productive agricultural practices, and thereby compromised their ability to sustain their livelihoods. In an 
interview with the leader of the community, Johannes Kraalshoek, he said: 'We lived well on this land. My ancestors also lived very well. We were never poor as our livelihoods were in our hands. This is in contrast to current conditions. We are just happy that we have part of our land back. Our economic conditions have not yet improved' (Kraalshoek 2014).

The policy of apartheid that led to their dispossession set them on the road of impoverishment. It was hoped that land reform would restore their previous success in agriculture and in sustaining their livelihoods and escaping from poverty. Unfortunately that has not yet happened.

\section{Life at Bethany before dispossession}

The land close to the Riet River, which was given to the missionaries for their work, was a well-watered area with three perennial fountains (Van Aswegen 1990, 230). Other than the availability of abundant water in Bethany, indigenous groups such as the Batswana were able to make the best of conditions in a dry climate. In a foreword to Legassick's (2010) thesis, Ross writes as follows about the Batswana: ' $[\mathrm{I}] \mathrm{n}$ general, the Tswana of the area were better able to exploit the dryland environment than the Griqua' (Ross in Legassick 2010, xii). According to the missionaries, the Batswana practice of agriculture was regarded as 'far superior to that of the "semi-civilised" Griquas... and the Sotho-Tswana were more advanced in "habits of industry and frugality" ' (Legassick 2010, 246). Whereas the Batswana were good crop farmers, even in times of drought, the Griquas were traders, hunters, herders (pastoralists), raiders rather than agriculturalists (Legassick 2010, 246). Ross $(1976,1)$ describes the Griquas as the hunters, gatherers and pastoralists. From an economic point of view it appears that the two groups, the Griquas and Batswana, complemented each other, instead of being in competition with each other, making the one group (Batswana) seem better than the other (Griquas), or the one 'semicivilised' (Griquas) and the other uncivilised (Batswana). Members of each group co-existed and complemented each other at Bethany, even before the arrival of the missionaries and before they were forcefully removed. In an interview with Johannes Kraalshoek, he said: 'Before we were forcefully removed we were able to make a living on the land. We were live-stock farmers and crop farmers. We would have been very far if we had not been forcefully removed. We also lived well together as the Griquas and Batswanas' (Kraalshoek 2014).

\section{Dispossession and impoverishment of the indigenous}

When the people of Bethany were forcefully removed and set on a journey of impoverishment, it was a continuation of the process of oppression, dispossession and impoverishment that started long before the infamous 1913 and 1936 Land Acts. Right from the beginning of colonialism the state alienated the original inhabitants 
from their land (Hebinck 2013,30). The story of dispossession and impoverishment of the people of Bethany, like that of others such as Sarah Baartman, is the story of 'millions who have known centuries of wretchedness' (Mbeki cited in Crais and Scully 2009, 166). The process of oppression, dispossession and impoverishment started right at the arrival of the Europeans in South Africa. According to Ntsebeza $(2007,108)$, this process of dispossession and impoverishment:

...started from the $17^{\text {th }}$ century when white settlers in South Africa, through a complex process of colonialism and land dispossession, ended up legally appropriating more than 90 per cent of the land, a process which was formalised with the passing of the notorious Native Land Act of 1913. The Act confined the indigenous people to reserves in the remaining marginal portions of land...As a result, the indigenous people were gradually converted from once successful farmers prior to the discovery of minerals, particularly gold in the $1860 \mathrm{~s}$, to poorly paid wage labourers.

In that way colonialism and apartheid systematically undermined African agriculture, whereas white farmers benefited from state subsidies as well (Ntsebeza 2007, 109). In addition to state subsidies, white capitalist agriculture flourished as a result of the availability of a captured cheap African labour (Ntsebeza 2007, 109).

Going back to the historical roots of dispossession, Bundy (1990) simplifies a complex process by outlining three forms of the process of dispossession. Firstly, the forcible dispossession by colonial conquest predates the period of forced removals. The Khoi and the San lost their grazing and hunting lands to Dutch settlers by force of arms (Bundy 1990, 4). The dispossession of indigenous peoples of the country predates the Land Acts of 1913 and 1936, as well as the policies of the National Party that came to power in 1948. Therefore, the forced removals of the people of Bethany and millions others during the 1960s were by no means the first efforts at forced removals or discriminatory practices.

Secondly Bundy (1990) points out that new economic forces and pressures severed people from their land. Peasant producers became involved in new economic obligations, such as paying rents and taxes; they fell into debts - and were put off their land by creditors. A cash economy provided new goods - and new pitfalls (Bundy 1990, 5). It must be pointed out that those economic forces and pressures were not neutral but favoured whites against indigenous peoples of the country. It must also be pointed out that the economic pressures were not aligned with market forces.

The third form was the role of the law, that is, the white man's law, accompanied by State intervention. Bundy $(1990,5)$ correctly points out that the law is not neutral. It reflects existing interests and the distribution of power in any society. The law in the nineteenth and twentieth century favoured the property owners and employing classes. The law favoured whites and was prejudiced against the indigenous people of South Africa. According to Bundy $(1990,5)$ there was nothing neutral about the Masters and Servants Act, the Vagrancy laws, the Land Acts of 1913 and 1936, the Urban Areas Act, or the Group Areas Act. 
Writing in the context of the dispossession of the Griquas, Ross (1976) cites H.J. and R.E. Simons who correctly said: '[T] he Griquas were destroyed because the colonists coveted their land' (Ross 1976). The Land Acts of 1913 and 1936 merely consolidated a deliberate and systematic process of dispossession that started right at the beginning of the colonial period. Bundy (1990) correctly points out that while the 1913 Land Act marked an important moment in the process of dispossession, it was 'part of a much longer and broader process'. This Act caused irreparable damages far broader than mere dispossession of land belonging to indigenous people. In a foreword to the legendary Sol Plaatje's book, Asmal said: 'The Native's Land Act of 1913 was not only an instrument for the creation of cheap labour but also the basis for the erosion and destruction of family and cultural life and the economy of Africans' (Asmal in Plaatje 2007, xi). It is for this reason that the land reform which addresses the land dispossessed since 1913, is inadequate. The cut-off date should have gone to a period far earlier than that. Emphasising the dispossession that predates the 1913 and 1936 Land Acts and answering the question: Who owns South Africa? Claassens $(1991,6)$ wrote as follows: '[E]xisting white title deeds are the result of wars of conquest, land grants to white settlers, and a market which was never free because the majority of the population was prohibited from either buying or leasing land'.

That systematic dispossession of the people of South Africa is the broader context of the dispossession of the people of Bethany and all the other victims of forced removals in South Africa. The people of Bethany were forcefully removed in 1963 and 1965 (Desmond 1971, 225; Murray 1996, 217). They shared this fate with 3,5 million people who were forcefully removed, who according to the then minister of Bantu Administration and Development, Mr M.C. Botha, 'liked and enjoyed being removed'. He is quoted to have said: 'The Bantu people like being moved...The Bantu people like the places where they are being resettled' (Desmond 1971, 23). How the apartheid regime failed to take notice of the resistance to forced removals defies any logic. Botha is also reported to have claimed that the people who were forcefully removed were volunteers: 'On occasions we have to do a great deal of persuasion to get them to move - but they are volunteers' (Desmond 1971, 18). Nothing is further from the truth, as many brutal and inhumane methods were used to remove the people forcefully, such as imprisonment, court orders, prosecution and imposition of penalties and threats of removing them to conditions that are even worse than those intended. When the people of Bethany were forcefully removed in the 1960s it was just a formalisation and consolidation of a process of dispossession that started with the arrival of the Europeans in Southern Africa. Dispossession was merely taken to a different level with the incorporation of their area by the British in 1848 , and finally taken to its logical conclusion by the giving of the land to the Berlin Mission Society in 1834 (Van der Stoep 2008, 78).

The process of dispossession to which the people of Bethany and more than 3,5 million others were subjected, was also a process of impoverishment, as they were 
moved to places where there were no houses and basic facilities, no arable land, no employment, and so forth. They were subjected to what Desmond refers to as 'abject poverty, malnutrition and starvation' (Desmond 1971, 17).

\section{The struggle for return of the land}

In 1993 the people of Bethany learnt of the news that the Evangelical Lutheran Church in Southern Africa (ELCSA), through its Property Management Company (ELCSA-PMC) intended to sell the land to commercial farmers (Murray 1996, 218). This led the claimants of Bethany to regroup and make plans to return to Bethany. Under the leadership of Johannes Kraalshoek the Bethany Land Committee ${ }^{2}$ met in September at the Ikageng Lutheran Youth Centre in Rocklands, Bloemfontein. Other meetings were later held at the Lutheran Church in Selosesha, Thaba-Nchu as well as in houses of the claimants. They met under the guidance of Philemon Tsese of the Free State Rural Committee, an affiliate of the National Land Committee. ${ }^{3}$ After years of struggle the community succeeded in 1998 to get back the land that they had originally occupied (Van der Stoep 2008, 78). This land claim was resolved in terms of the Restitution Act of 1994, which provides for the restitution of land rights to persons and communities which were dispossessed after 19 June 1913.

\section{The land reform policies and legislation}

The restoration of the land to the people of Bethany came as a result of the land reform policies and legislation brought about by the new government led by the African National Congress (ANC). These are the policies and legislation that according to Hall $(2007,87)$ are 'an ambitious initiative'. These policies and pieces of legislation followed years of struggle during the era of apartheid as communities rallied together under the leadership of the National Land Committee and its affiliates. In the case of the community of Bethany the National Land Committee affiliate was the Free State Rural Committee (OFSRUC). Political parties such as the ANC, PAC and AZAPO also placed the land question on the national agenda, even before the CODESA negotiations. Hebink $(2013,37)$ correctly states that land reform had started even before the new government led by the ANC took control of the country in 1994.

2 Other committee members were Messrs Andrew Bahumi, Cornelius Oliphant, Elias Sefuna and Dawid Maarman and Mrs Paulina Bonyonyo (Die Volksblad, 9 September 1993).

3 The author had the privilege of growing up with and attending schools with Mr Philemon Tsese and working for the affiliates of the National Land Committee (TRAC and OFSRUC) as a fieldworker and a researcher. As a fieldworker of the Free State Committee the author attended some of the meetings of the Bethany Land Committee in Bloemfontein and Thaba Nchu. In addition the author also earlier rendered pastoral services to farm workers who were employed by the Property Management Company of ELCSA, either sent by or accompanying Dean J. Brits in 1991 together with Mr J. Kraalshoek, who was church elder of Bloemfontein East Parish. 
According to Changuion and Steenkamp (2012):

The takeover of the government by a predominantly black governing party in 1994, apart from other changes, also ushered in a totally new policy on land tenure (land reform) in South Africa. This policy was focussed on rectifying the imbalance in land tenure, in other words, to take land from white land owners, who owned by far the greater portion of agricultural land, and make it available to the black population group who comprised between $75 \%$ and $80 \%$ of the total population of the country.

Land tenure is just one of the three pillars of land reform. The other two pillars are land restitution and land redistribution. Therefore, land tenure as referred to by Changuion and Steenkamp (2012) is only one component of the Land Reform Policy which is outlined in the White Paper on Land Reform by the Department of Land Affairs (Department of Land Affairs 1998). The process of addressing the imbalances of the past was enabled by the promulgation of The Restitution of Land Rights Act, 1994 (Act No. 22 of 1994), which has been amended a number of times.

With these land reform policies and pieces of legislation, the government intended to restructure the agricultural sector by transferring access to and ownership of land from whites to Africans in view of redressing the injustices of colonial and apartheid dispossession (Hall 2007, 87). It also wanted to transform social and economic relations in the country (Hall 2007, 87). These good intentions and ambitious initiatives continue to be frustrated by the inclusion of the property clause in the Constitution of the Republic of South Africa, as well as the principle of the willing buyer, willing seller. This inclusion of the protection of property rights and the willing seller, willing buyer principle continue the imbalance of the past. It also complicates land reform. It is one of the major reasons for the slow pace of implementation of the land reform programmes. Mayende, a former land claims commissioner, raised the issue of the problematic nature of this inclusion of the property clause (Mayende 1998, 98). He points out that many see the property clause as the Achilles heel of the land reform process, as the clause is one of the most disabling compromises ever to emerge out of the Constitutional negotiations held between the years 1991-1994 (Mayende 1998, 99). It is a major obstacle to genuine land reform and has serious implications for the indigenisation and development of the agrarian economy (Mayende 1998, 99). This problematic nature of the property clause in the Constitution is also recognised by Ntsebeza $(2007,107)$ who reiterated the arguments of the critics that 'the property clause in the Constitution is the main obstacle to large scale land redistribution in South Africa'.

The Restitution of Land Rights Act of 1994 automatically replaced the Land Acts of 1913 and 1936, according to which blacks were dispossessed, thereby removing statutory racial discrimination regarding ownership of land, occupation and leasing of land and property (Changuion and Steenkamp 2012, 273). However, the removal of racial discrimination remains only statutory, as in reality the imbalance in land ownership is still intact. 
All the laws related to land reform and restitution had as one of the main objectives 'poverty reduction' and enhancement of livelihoods (Liber, Maluleke, Manenzhe, Parada and Cousins 2013, 1, 3). According to Liber et al $(2013,1)$ after two decades there is near-consensus that the programme of land reform has performed poorly. According to Liber et al $(2013,2)$ indicators of poor performance are inter alia as follows:

1. Few people have benefited from land reform.

2. Those who benefited did so very modestly.

3. In some cases the wrong people have benefited.

In addition, there is consensus that the post-settlement agricultural support systems are weak and inadequate (Liber et al 2013,2). The whole pace of land reform is very slow and tentative (Hall 2007, 87; Ntsebeza 2007, 107). Bethany is a typical example of weak and inadequate post-settlement support that has not succeeded in terms of poverty reduction and enhancement of livelihoods. In the case of Bethany, those who have returned have replaced the urban unemployment with rural unemployment. Bethany is likely to share the fate of many projects that have collapsed (Liber et al 2013,2). For fear of the possibility of such a collapse, some claimants have not yet returned to Bethany. The absence of infrastructural development and other services continues to be a deterrent that discourages especially young people from relocating back to the land that they have successfully claimed back.

\section{The life of those who returned to Bethany}

While appreciating the return of their land, the people of Bethany share the poverty that affects the majority of South Africans - the poor blacks. It is probably for that reason that many have still not yet physically returned to Bethany, as there are no employment opportunities, there is an absence of schools, and they experience transport challenges in commuting to Bloemfontein and surrounding towns. They are negatively affected by what Terreblanche calls 'a contradictory legacy' of colonialism and apartheid (Terreblanche 2002, 4, 25). This legacy that the people of Bethany share with many black South Africans is marked by 'major socioeconomic problems including high levels of unemployment, the abject poverty of the population, sharp inequalities in the distribution of income' (Terre blanche 2002,4). Terreblanche writes as follows in the context of the broader South African society:

...most unemployed people are Africans; more Africans than any others live in abject poverty; the inequalities in the distribution of income, property, and opportunities are mainly to the detriment of Africans; and it is largely Africans who were criminalised during the long periods of repression, discrimination and violence, who are the main victims of criminality and violence. (Terreblanche 2002, 25) 
The political liberation and associated changes have 'not yet translated into socioeconomic empowerment' (Terreblanche 2002, 35). The South African government also recognises the contradictory legacy that has been bequeathed to the country by colonialism and apartheid, particularly with respect to land ownership. In the foreword to the White Paper on Land Reform of 1998, the then Minister of Land Affairs, Mr Derek Hanekom wrote: 'Our history of conquest and dispossession, of forced removals and a racially-skewed distribution of land resources, has left us with a complex and difficult legacy' (Hanekom in Department of Land Affairs 1998). What Sol Plaatjes said in 1916 in his book, is still a reality to millions of dispossessed South Africans, even to those whose land has been returned: 'Awakening on Friday morning, June 20, 1913, the South African native found himself, not actually a slave, but a pariah in the land of his birth' (Plaatje 2007, 21). They still live in conditions marked by poverty. Those who have returned are still impoverished. In its review of the Recapitalisation and Development Programme (RADP), the Department of Rural Development and Land Reform also correctly and honestly acknowledges challenges of most land reform projects, stating inter alia, that: 'It is identified that most land reform projects were not successful and thus in distress, due to lack of adequate and appropriate post-settlement support' (Rural Development and Land Reform 2013).

\section{CONCLUSION}

This article traces the history of a community that lived at Bethany, a former mission station of the Berlin Mission Society, which has now handed out its properties to the Evangelical Lutheran Church in Southern Africa (ELCSA). The land on which the mission station was established in 1834 was given by Adam Kok II to the Berlin Mission Society for the spread of the gospel and the education of the indigenous people. This is the land that was initially inhabited by the Griquas, Koranas and Batswana. Their descendants were forcefully removed by the apartheid regime in 1939 and in the 1960s. The article goes back into history to trace the journey of impoverishment to which they have been pushed by the policy of forced removal to which they were subjected in the past. It argues that before the forced removal they were able to sustain their community. They were live-stock and crop farmers. This was disrupted when they were forcefully removed. When they returned to the ancestral land, it was not only about ownership but in line with one of the main purposes of land reform, namely reduction of poverty and enhancement of livelihoods - it was hoped that they would escape poverty. Unfortunately that has not been the case. The challenge is on relevant government departments to review the postsettlement support and ensure that land reform programmes contribute substantially to enhancement of livelihoods and poverty reduction. Equally the Lutheran Church, which was initially allocated the land in view of enabling them to carry out mission 
work and the development of the community by Adam Kok, must also play an active, constructive role in the fight against poverty as part of its task 'to pronounce the truth, justice and compassion', to use the words of Seremane $(1998,93)$. There must be a consultative process which critically reviews the socio-economic conditions of those who have returned to their ancestral land and search for ways of building their capacity, facilitating ongoing post-settlement support and enlisting the support and mentorship of successful farmers who are sympathetic to land reform.

\section{LIST OF REFERENCES}

Berlin Mission Society. 2013. History online. http://www.sahistory.org.za/topic/berlin_mission_ society (accessed 7/04/2013).

Bundy, C. 1990. Land, law and power: Forced removals and the law in South Africa. In No place to Rest: Forced removals and the law in South Africa, C. Murray and C. O'Regan (Eds). Cape Town: Oxford University Press.

Changuion, L. and Steenkamp, B. 2012. Disputed land: The historical development of the South African Land issue, 1652-2011.

Claassens, A. 1991. Who owns South Africa? Can the repeal of the Land Acts de-racialise land ownership in South Africa? Johannesburg: Centre for Applied Legal Studies, Wits.

Crais, C. and Scully, P. 2009. Sarah Baartman and the Hottentot Venus: A ghost and a biography. Johannesburg: Wits University Press.

Department of Land Affairs. 1998. White Paper on the South African Land Reform. Pretoria: Department of Land Affairs.

Desmond, C. 1971. The discarded people. Braamfontein: The Christian Institute.

Die Volksblad, 9 September 1993.

Du Plessis, J. 1911. Christian Missions in South Africa. London: Longmans, Green.

Hall, R. 2007. Transforming rural South Africa? Taking stock of land reform. In The land question in South Africa, L. Ntsebeza and R. Hall (Eds). Cape Town: HSRC, pp. 87-106.

Hebinck, P. 2013. Land and agrarian reform policies from a historical perspective. In In the shadow of policy: Everyday practices in South African land and agrarian reform, P. Hebinck and B. Cousins (Eds). Johannesburg: Wits University Press, pp. 20-45.

Kraalshoek, J. 2014. An interview with Mr Kraalshoek on 8 January 2014 at Bethany.

Legassick, M.C. 2010. The politics of a South African frontier: The Griqua, the Sotho-Tswana and the missionaries. Bassel: Basler Africa Bibligraphien.

Liber, M., Maluleke, T., Manenzhe, T., Parada G. and Cousins, B. 2013. Land reform and livelihoods: Trajectories of change in northern Limpopo Province, South Africa. Cape Town: HSRC.

Mayende, P. 1998. The church and land restitution: Time to deliver. In Church land and poverty, D. Gillian (Ed). Johannesburg: Progress Press.

Mbeki, T. 1999. I am an African. In The life and times of Thabo Mbeki, A. Handland and Rantao. Rivonia: Zebra, 153-158. 
Molema, S.M. 2012. Lover of his people: A biography of Sol Plaatjie. Johannesburg: Wits University, translated by D.S. Matjila and K. Haire.

Murray, C. 1996. Land reform in the Eastern Free State: Policy dilemmas and political conflicts. The Journal of Peasant Studies 23(2-4): 209-244.

Ntsebeza, L. 2007. Land redistribution in South Africa: The property clause revisited. In The land question in South Africa, L. Ntsebeza and R. Hall (Eds). Cape Town: HSRC, pp. 107-132.

Pakendorf, G. 2013. A brief history of the Berlin Mission Society. http://onlinelibrary.wiley. com/10.111 (accessed 6/4/2013).

Penn. N. 1990. The forgotten frontier: Colonists and Khoisan on the Cape's northern frontier in the $18^{\text {th }}$ century. Cape Town. Double Story Books.

Plaatje, S. 2007. Native live in South Africa. Northlands: Picador Africa.

Raper, P.E. 1987. Dictionary of Southern African place names. Rivonia: HSRC.

Ross, R. 1976. Adam Kok's Griquas: A study in the development of stratification in South Africa. Cambridge University Press.

Rural Development and Land Reform Department. 2013. Three year review of recapitalisation and development programme. Pretoria: Rural Development and Land Reform.

Schoeman, K. 1985. Die huis van die armes: Die Berlynse Sendinggenootskap in die OVS. Kaapstad: Human \& Rosseau.

Schoeman, K. 1996. J.J. Kichner en die vroeë sending, 1799-1806. Kaapstad: Suid Afrikaanse Biblioteek.

Schoeman, K. 1997. Dogter van Sion: Machtelt Smit en die 18de-eeu samelewing aan die Kaap, 1749-1799. Kaaptad: Human \& Rousseau.

Schoeman, K. 2002. The Griqua captaincy of Philippolis, 1826-1861. Pretoria: Protea Book House.

Schoeman. K. 2003. The early white travellers in the Transgariep, 1819-1840. Pretoria: Protea Book House.

Schoeman, K. 2005. The Griqua Mission at Philippolis. Pretoria. Protea Book House.

Schoeman, K. 2009. The seven lives: Cape biographies of the seventeenth century. Pretoria: Protea Book House.

Seremane, J. 1998. The role of the church in SA Land Reform Programme. In Church, land and poverty, D.S. Gillian (Ed). Johannesburg: Progress Press, pp. 93-103.

Terreblanche, S. 2002. A history of inequality in South Africa. Pietermaritzburg: University of Natal Press.

Van Aswegen, H.J. 1990. History of South Africa. Pretoria to 1854. Pretoria: Van Schaik.

Van der Stoep, J. 2008. Do minorities need cultural rights? The case of the Griqua people in South Africa. In From our side: Emerging perspectives on development and ethics, S. de Gruchy, N. Koopman, S. Strijbos (Eds). Amsterdam: Rozenburg, pp. 75-86.

Venter, A., Marais, K., Van Zyl, D., Van Rooyen, D. and Cloete, J. 2010. A socio-economic and cultural study of the Griqua people in South Africa. Bloemfontein: CDS. UFS.

Visagie, J. 2012. Migrasie en die gemeenskappe noord van die Oranjerivier. In Geskiedenis van Suid Afrika: Van voortye tot vandag, F. Pretorius. Kaapstad: Tafelberg.

Welsh, F. 2000. A history of South Africa. London: Harper Collins Publishers. 